\title{
アトピー性皮膚炎に対する草津温泉療法の効果
}

\author{
久保田一雄* 町田 泉* 田村 耕成* \\ 倉 林 均* 白倉卓夫*
}

\section{Effects of Balneotherapy on Atopic Dermatitis at Kusatsu}

\author{
Kazuo Kubota, ${ }^{*}$ Izumi Machida, ${ }^{*}$ Kousei Tamura, ${ }^{*}$ \\ Hitoshi Kurabayashi, ${ }^{*}$ Takuo Shirakura*
}

\begin{abstract}
From June 1990 to May 1995, 46 patients with atopic dermatitis (31 males and 15 females, $25 \pm 11$ years) were admitted to our hospital to receive balneotherapy using Kusatsu hot-spring water. The atopic dermatitis in all but 4 cases occurred while the patients were still under 20 and had been refractory to various treatments including steroid ointment therapy over a long period of time. A week's observation allowing only a hot fresh water shower to remove environmental factors, resulting in no change in their skin symptoms and pruritus, was followed by taking a 10 -minute $40-42{ }^{\circ} \mathrm{C}$ hot-spring bath $1-2$ times daily for 3-28 consecutive weeks. The $\mathrm{pH}$ of the hot-spring water is 2.0 and its main components are aluminium, sulphates and chlorides. The skin symptoms of 32 out of 46 cases were improved through hot hot-spring bathing and furthermore pruritus was improved in 18 out of the 32 cases. The improvement of skin symptoms was supported by a significant decrease in serum LDH levels. In contrast, pruritus was not inproved in the remaining 14 cases who showed no changes in skin symptoms and serum LDH levels. Moreover, changes in the number of Staphylococcus aureus on the skin surface were examined before and after balneotherapy. In the 21 cases examined whose skin symptoms were improved, many Staphylococci aureus were detected in 15 of the cases but not in the other 6 cases before starting the balneotherapy. However, they disappeared in 13 out of the 15 cases and decreased in the remaining 2 cases through the balneotherapy. On the other hand, the number of Staphylococcus aureus on the skin surface was not changed in 6 out of the 7 cases whose skin symptoms were not improved. The mechanisms of the improvement of skin symptoms through hot hot-spring bathing may be explained by considering that acute flares induced by skin infiltration due to Staphylococcus aureus subsided with exposure to the acidic hot-spring water. Therefore, balneotherapy at Kusatsu can be useful for the treatment of refractory cases of atopic dermatitis. (Jpn J Rehabil Med 1997 ; 34 : 40-45)

要 旨: 平成 2 年 6 月からの 5 年間に 46 例のアトピー性皮膚炎患者（男性 31 例，女性 15 例, $25 \pm 11$ 歳) に対して, 草津温泉療法 $\left(40 \sim 42^{\circ} \mathrm{C}, 1\right.$ 回 10 分, 1 日 $1 \sim 2$ 回) を $3 \sim 28$ 週行 った。 その泉質は酸性（pH 2.0)-アルミニウム-硫酸塩・塩化物温泉である. 32 例（70\%）で 皮膚症状が改善し，さらにそのうち 18 例で掻㾕も改善した。皮膚症状の改善は血清 LDH の 有意な低下でも襄付けられた。皮膚症状改善例のうち，温泉療法前に皮膚表面に多数の黄色ぶ ぞう球菌が検出された 15 例では, 温泉療法後に 13 例で消失, 2 例で減少した。この草津温泉 療法による皮膚症状の改善機序として, 皮膚病変の増悪因子である黄色ぶどう球菌に対する酸 性温泉水の殺菌作用が推定される。（リハ医学 $1997 ； 34: 40-45)$
\end{abstract}

Key words : アトピー性皮膚炎 (atopic dermatitis), 温泉療法 (balneotherapy), 酸性温 泉水 (acidic hot-spring water), 黄色ぶどう球菌（Staphylococcus aureus）

1996 年 5 月 29 日受付, 1996 年 8 月 1 日受理

* 群馬大学医学部附属病院草津分院内科リハビリテーション部/テ 377-17 群馬県吾妻郡草津町草津 $627-3$

Department of Medicine and Division of Rehabilitation, Kusatsu Branch Hospital, Gunma University School of Medicine 


\section{はじめに}

最近の十数年間に, 小児とともに成人のアトピー性 皮膚炎患者も増加し，大きな社会問題に発展してきた が1,2), その原因として, 私達を取り巻く衣食住環境 の変化が指摘されている2 ${ }^{2 \sim 4}$. この難治性のアトピー 性皮膚炎に対しては長い間ステロイド外用薬が第一選 択剤として汎用されてきたが，この治療法も対症療法 にすぎないばかりか, 乱用によって種々の副作用を引 き起こし，時には患者を苦しめる原因にもなってい る ${ }^{2,3)}$.このステロイド療法を含む西洋医学的治療や, 鍼・众などの東洋医学的治療の他に, 多くの民間療法 が試みられているが，いずれも決定的な治療法ではな $い^{3)}$.

このように現時点では本症を治㾍に導く治療法は確 立されていないので，本症の患者の中には長期にわた って皮膚症状や搔痒に苦しめられ，社会生活の制限を 余儀なくされ，閉鎖的態度をとる症例も少なくない. 私達の病院では, このような患者を受け入れ, 草津温 泉水を用いた治療を試みてきた。「草津温泉療法」が 難治性アトピー性皮膚炎を治癒させ得るとはとても考 えられないが, 少なくとも一部の患者の皮膚症状と搔 痒の改善には効果があると思われる。本論文では, ア トピー性皮膚炎に対する草津温泉療法の効果を検討し た成績を報告する。

\section{方法}

患 者：対象法平成 2 年 6 月から平成 7 年 5 月まで の 5 年間に当院内科に入院した 46 例のアトピー性皮 膚炎 ${ }^{2,5)}$ の患者（男性 31 例，女性 15 例）で，年齢分 布は $13 \sim 80$ 歳, 平均値士標準偏差值は $25 \pm 11$ 歳, 中 央值は 21 歳であった。発症年齢は $0 \sim 75$ 歳で, 平均 值士標準偏差值は $9 \pm 13$ 歳, 中央值は 4 歳であった。 4 例は 20 歳を過ぎてからの発症で，それぞれ $23 ， 31$, 42, 75 歳時の発症であった。罹病期間は 2 31 年で, 平均值士標準偏差值は $16 \pm 7$ 年, 中央值は 16 年であ った。全例当科受診前に既に少なくとも二つ以上の病 院または医院の皮膚科医師の診断・治療を受けてい て, 全例ステロイド軟膏治療を少なくとも 1 年から数 年間受けていた既往があったが，当科入院時には全例 中止していた。な扔，本症が慢性に経過することや， 医師から治療内容について十分説明を受けていなかっ たことなどから，その他の治療法の詳細を知ることは
難しかった．当科でも改めて上原の診断基準 6 ( や日本 皮膚科学会の診断基準 (6) に基づいて診断を確認した. その結果，全例典型的なアトピー性皮膚炎と診断され た。表 1 に示した病型分類（当科案）によると限局型 6 例，全身型 40 例であった．気管支喘息 ${ }^{7}$ を合併し ていた症例は 11 例，白内障を合併していた症例は 3 例であった。また, 当科入院時には膿痂疹などの感染 症を併発していた症例はいなかった。

草津温泉療法：当院で使用している草津温泉水は, 無色透明で, その泉質は表 2 に示したように酸性 (pH 2.0)-アルミニウム一硫酸塩・塩化物温泉であ る ${ }^{8)}$. 患者には入院後 1 週間は真湯シャワー浴だけを 許可し皮膚症状や蛍詳の推移を観察した後, 温泉浴を 開始した。温泉浴の方法は $40 \sim 42^{\circ} \mathrm{C}, 10$ 分, 坐位浴 で, 1 日 $1 \sim 2$ 回である ${ }^{9)}$. 温泉浴開始当初の $1 \sim 2$ 週 間, 入浴後温泉水の刺激により皮膚に疼痛を感じた場 合には，出浴後直ちに真湯シャワー浴で皮膚に付着し た温泉成分を洗い落とさせた。顔の症状の強い症例に は, 顔も手ですくった温泉水に浸させた。また，搔痒 に対しては抗ヒスタミン剤（内服）を投薬し，皮膚の 乾燥に対してはワセリンを使用させた. 全例入院中, ステロイド軟膏，ステロイド内服剤を使用しなかっ た。

皮膚病変の効果判定：アトピー性皮虐炎に対する治 療の効果を判定する特別の基準は報告されていない. その判断は一般的には視診による. 本研究では, 患者 の承諾を得て, 入院時に皮膚病変部位を写真撮影し, 退院時の効果判定に使用した。皮膚病変に対する効果 判定は, 病変部位の $(1)$ 発赤, (2) 腫脹, (3) 湿潤, (4) 落屑, (5) 苔痽,，(6)角化や亀裂，(7) 蛍爬痕の 7 項目に注目して ${ }^{2)}$, 明らかに改善した症例を皮膚症 状改善と判断し，やや改善というようなあいまいな判 定は避けた。また，明らかに悪化した症例は皮膚症状 悪化, それ以外の症例は皮膚症状不変と判定した。

血液免疫学的検査：温泉療法開始前日と終了翌日の 午前 8 時に血液を採取し, 以下の検査を行った. 血液 リンパ球数と好酸球数 (Coulter 社製自動血球測 定器), $\mathrm{CD} 3, \mathrm{CD} 4, \mathrm{CD} 8, \mathrm{CD} 4 / 8$ 比 (Flow-

表 1 アトピー性皮膚炎の病型分類（当科案）

限局型：皮膚病変が好発部位（顔，頸，軀幹，肘窩， 手, 膝响, 足) の 1 または数部位に限局

全身型：皮膚病変が全身に分布 
表 2 草津温泉水 $1 \mathrm{~kg}$ 中の成分

\begin{tabular}{lrl}
\hline \multicolumn{1}{c}{ 分 } & $\mathrm{m}$ 成 & mval \\
\hline 陽イオン & & \\
ナトリウム $\left(\mathrm{Na}^{+}\right)$ & 53.7 & 2.33 \\
カリウム $\left(\mathrm{K}^{+}\right)$ & 16.0 & 0.41 \\
マグネシウム $\left(\mathrm{Mg}^{2+}\right)$ & 39.0 & 3.21 \\
カルシウム $\left(\mathrm{Ca}^{2+}\right)$ & 72.0 & 3.60 \\
鉄 $\left(\mathrm{Fe}^{2+}\right)$ & 14.5 & 0.52 \\
マンガン $\left(\mathrm{Mn}^{2+}\right)$ & 1.4 & 0.05 \\
アルミニウム $\left(\mathrm{Al}^{3+}\right)$ & 39.0 & 4.34 \\
水素 $\left(\mathrm{H}^{+}\right)$ & 10.1 & 10.0 \\
陰イオン & & \\
フッ素 $\left(\mathrm{F}^{-}\right)$ & 12.0 & 0.63 \\
塩素 $\left(\mathrm{Cl}^{-}\right)$ & 343.0 & 9.68 \\
硫酸 $\left(\mathrm{SO}_{4}{ }^{2-}\right)$ & 611.0 & 12.7 \\
硫酸水素 $\left(\mathrm{HSO}_{4}^{-}\right)$ & 206.0 & 2.12 \\
非解離成分 & & \\
メタケイ酸 $\left(\mathrm{H}_{2} \mathrm{SiO}_{3}\right)$ & 250.0 & $3.21(\mathrm{mmol})^{*}$ \\
メタホウ酸 $\left(\mathrm{HBO}_{2}\right)$ & 8.2 & $0.19(\mathrm{mmol})$ \\
\hline
\end{tabular}

群馬大学医学部附属病院草津分院内の温泉水の成分. $\mathrm{pH} 2.0$. 溶存物質（ガス性の物質を除く） $1.6759 \mathrm{~g} /$ kg. なお，本温泉水の源泉である湯畑では $\mathrm{H}_{2} \mathrm{~S}$ が 4.8 $\mathrm{mg} / \mathrm{kg}$ 含まれているが, 当病院で使用している温泉水 からは $\mathrm{H}_{2} \mathrm{~S}$ は検出されない（群馬県衛生公害研究所の 分析資料より作成).

*非解離成分のみ $\mathrm{mmol}$ で表示.

cytometry 法), PHA, Con A に対する反応性 $\left({ }^{3} \mathrm{H}\right.$ thymidine 法), $\mathrm{NK}$ 細胞活性 $\left({ }^{51} \mathrm{Cr}\right.$ 遊離法), 血清 $\operatorname{IgG}, \operatorname{Ig} \mathrm{A}, \operatorname{IgM}$ 濃度 (免疫比濁法), 血清 IgE 濃度 (酵素免疫測定法), 血清 LDH (酵素法), 血清 LDH アイソザイム (セルロースアセテート膜電気泳動法).

皮膚表面黄色心゙どう球菌数の算定：温泉療法開始前 日と終了翌日の午前 8 時に, Williams らの方法に従 って，スタンプ法で実施した ${ }^{10)}$.フードスタンプ （TGSE 塞天培地，日水社製）の蓋をとり，患者の左

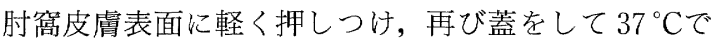
48 時間培養し, 培地中央の $4 \mathrm{~cm}^{2}$ のコロニー数を算 定した。結果は $1 \mathrm{~cm}^{2}$ 当りのコロニー数が，0 個の場 合 $(-), 1 \sim 10$ 個の場合 $(+), 11 \sim 100$ 個の場合 $(2+) ， 101$ 個以上の場合を（3+）と表記した。

\section{結果}

入院日数は 26〜204 日で, 平均值士標準偏差值は $79 \pm 48$ 日，中央值は 60 日であった。まず，1 週間温 泉浴を行わないで, 真湯シャワー浴だけで経過を観察 したが，1例も皮膚症状や搔痒などに改善傾向は認め られなかった。
草津温泉療法によって皮膚症状は 32 例（70\%）で 改善したが，14 例 $(30 \%)$ では不変であった。悪化 した症例は 1 例もなく，湯ただれ（酸性泉浴湯皮膚

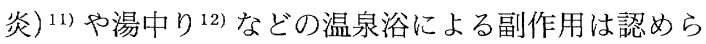
机なかった。皮虐症状改善 32 例中 5 例，不変 14 例中 6 例は気管支喘息合併例であった。全身型法 40 例中 26 例で, 限局型は 6 例全例で皮膚症状が改善した。 なお，皮膚病変に対する効果判定に用いた 7 項目につ いては，皮膚症状改善例では全項目改善し，項目ごと の差異は認められなかった。温泉療法前後で変化した 血液免疫学的検查成績は，血清 LDH だけで，皮膚症 状改善例では有意に低下したが，不変例では変化しな かった(表 3)。 その他の検査には特に変化が認められ なかった。ただ，温泉療法開始前の成績では，皮膚症 状改善例に比べて不変例では, 好酸球, 血清 $\mathrm{IgE}$ 及 び血清 LDH が有意の高值であった(表 3).

図 1 に温泉療法前後に皮膚表面黄色ぶどう球菌を検 討した成績を示した．皮虐症状改善例では 21 例で検 索できたが，温泉療法開始前から陰性 6 例を除いた 15 例では，13 例で消失，2例で減少であった。温泉 療法開始前から陰性の症例は終了後も陰性であった。 これに反して, 皮膚症状不変例では, 検索できた 7 例 中，消失した症例は 1 例だけで，残りの 6 例は不変で あった。しかも，そのうちの5例は（3+）のままで あった。

掻痒については，皮膚症状改善 32 例中 18 例 （56\%）で改善，14 例（44\%）で不変で，悪化した症 例は 1 例もいなかった。一方，皮膚症状不変 14 例で は蛍痒は全く改善しなかった。まとめると，皮虚症状 に対する有効率は $70 \%$ ，搔痒に対する有効率は $39 \%$ であった，湯ただれ（酸性泉浴湯皮膚炎）や湯中りな どの温泉浴による副作用は全く認められなかったの で，安全性は 100\%で，有用性は70\%であった。

\section{考察}

本研究ではアトピー性皮膚炎に対する草津温泉療法 の効果を検討した。その結果は，皮膚症状に対する有 効率は $70 \%$, 蛍痒に対する有効率は $39 \%$ であった。 湯ただれ (酸性泉浴湯皮膚炎) や湯中りなどの温泉浴 による副作用は認められなかったので, 安全性は $100 \%$ で，有用性は $70 \%$ であった，入院直後 1 週間温 泉浴を行わないで, 真湯シャワー浴だけの観察期間を 置いたが何の改善も認められなかったので, 上記の結 
表 3 草津温泉療法前後の血液免疫学的検查成績

\begin{tabular}{|c|c|c|c|c|}
\hline \multirow{2}{*}{ 検查項目 } & \multicolumn{2}{|c|}{ 皮膚症状改善例 (32 例) } & \multicolumn{2}{|c|}{ 皮膚症状不変例 (14 例) } \\
\hline & 温泉療法前 & 温泉療法後 & 温泉療法前 & 温泉療法後 \\
\hline リンパ球 & $2,580 \pm 990(32)$ & $2,240 \pm 890$ & $2,410 \pm 1,160(14)$ & $2,140 \pm 680$ \\
\hline 好酸球 & $730 \pm 540(32)$ & $650 \pm 530$ & $1,370 \pm 980(14)^{*}$ & $1,710 \pm 1,330$ \\
\hline CD 4 陽性細胞 & $38.0 \pm 9.7(20)$ & $38.2 \pm 5.0$ & $44.8 \pm 10.1(10)$ & $44.1 \pm 7.9$ \\
\hline CD 8 陽性細胞 & $28.5 \pm 5.4(20)$ & $27.9 \pm 4.3$ & $28.4 \pm 6.1(10)$ & $28.6 \pm 6.5$ \\
\hline $\mathrm{CD} 4 / 8$ 比 & $1.46 \pm 0.36(20)$ & $1.40 \pm 0.35$ & $1.71 \pm 0.69(10)$ & $1.68 \pm 0.70$ \\
\hline PHA 反応性 & $179 \pm 72(20)$ & $197 \pm 157$ & $244 \pm 153(11)$ & $202 \pm 199$ \\
\hline Con A 反応性 & $151 \pm 70(20)$ & $168 \pm 119$ & $204 \pm 122(11)$ & $167 \pm 131$ \\
\hline NK 細胞活性 & $30 \pm 15(14)$ & $29 \pm 13$ & $21 \pm 11(7)$ & $19 \pm 10$ \\
\hline 血清 IgG & $1,430 \pm 300(32)$ & $1,520 \pm 310$ & $1,410 \pm 350(14)$ & $1,430 \pm 270$ \\
\hline 血清 IgA & $243 \pm 77(32)$ & $261 \pm 104$ & $276 \pm 118(14)$ & $263 \pm 102$ \\
\hline 血清 IgM & $150 \pm 73(32)$ & $154 \pm 75$ & $161 \pm 87(14)$ & $157 \pm 100$ \\
\hline 血清 IgE & $3,860 \pm 4,270(32)$ & $3,660 \pm 4,420$ & $9,960 \pm 5,150(14)^{\dagger}$ & $8,260 \pm 4,970$ \\
\hline 血清 LDH & $412 \pm 141(32)$ & $321 \pm 87 \ddagger$ & $538 \pm 183(14)^{\S}$ & $583 \pm 187$ \\
\hline アイソザイム LDH 5 & $10 \pm 3(27)$ & & $12 \pm 9(10)$ & \\
\hline
\end{tabular}

単位と正常值：リンパ球 $(800 \sim 6,000 / \mu 1)$, 好酸球 $(40 \sim 500 / \mu 1)$, CD 4 陽性細胞 $(25 \sim 56 \%)$, CD 8 陽性細胞 $(17 \sim 44 \%), \mathrm{CD} 4 / 8$ 比 $(0.6 \sim 2.9)$, PHA 反応性 $(60 \sim 530 \mathrm{SI})$, Con A 反応性 $(47 \sim 486 \mathrm{SI})$, NK 細胞活性 (18〜 40\%), 血清 $\operatorname{IgG}(680 \sim 1,620 \mathrm{mg} / \mathrm{dl})$, 血清 $\operatorname{IgA}(84 \sim 438 \mathrm{mg} / \mathrm{dl})$, 血清 $\operatorname{IgM}(57 \sim 288 \mathrm{mg} / \mathrm{dl})$, 血清 $\operatorname{IgE}(250 \mathrm{U} /$ $\mathrm{ml}$ 以下), 血清 $\mathrm{LDH}(50 \sim 400 \mathrm{IU} / l)$ ，アイソザイム LDH $5(5 \sim 11 \%)$. 数值はすべて平均值土標準偏差值を示す. 括弧 内の数字は検索した症例数を示す.

*皮盧症状改善例と不変例の温泉療法前の好酸球は有意な差異 $(p<0.01)$.

†皮膚症状改善例と不変例の温泉療法前の血清 $\operatorname{IgE}$ は有意な差異 $(p<0.05)$.

ま皮膚症状改善例の温泉療法前と温泉療法後の血清 LDH は有意な差異 $(p<0.005)$.

$\S$ 皮膚症状改善例と不変例の温泉療法前の血清 $\mathrm{LDH}$ は有意な差異 $(p<0.025)$.

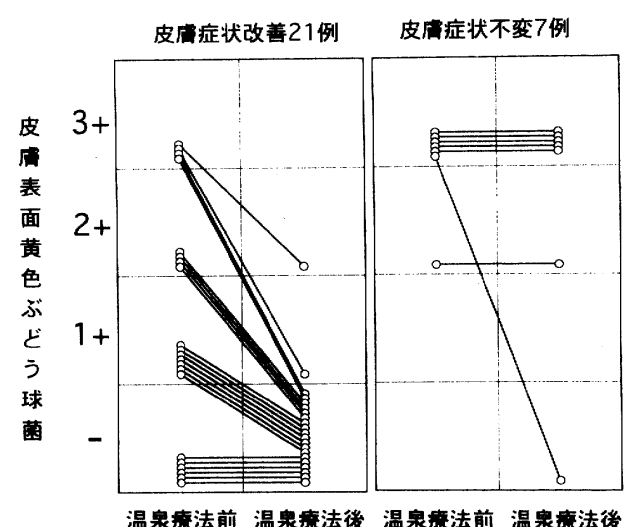

図 1 草津温泉療法前後の皮膚表面黄色ぶどう球 菌の変化

果は草津温泉療法による効果と思われる ${ }^{4,13)}$. 皮膚症状に対する効果は一般に視診で判定される。 皮膚症状の程度をスコア化した報告もあるが，その基 になる点数もやはり視診による ${ }^{14)}$. 本研究では視疹に よる判定の目安として, 万法に示した 7 項目を選び, 入院時に撮影した写真も用いて皮膚症状を改善, 不 変, 悪化に判別した。 また, 向井らが報告しているよ
うに皮膚症状と血清 LDH は相関するので14), 本研究 でも血清 LDH を検討した。血清 LDH は皮膚症状改 善 32 例では温泉療法後に有意に低下したが, 皮膚症 状不変 14 例では変化しなかったので, 血清 LDH の 変化は視診による判定を客観的に支持すると考えられ る ${ }^{14)}$. なお, この血清 LDH の増加は主として LDH5 による ${ }^{14)}$. 本研究でも, LDH5 は皮膚症状不変 14 例 でやや高い傾向が認められたが，測定值そのものが狭 い範囲内での変化なので, 統計的に有意な変化には至 らなかった。

他の検索できた血液免疫学的検査には，温泉療法後 に変化した項目はなかった，ただ，温泉療法開始前の 検査で, 温泉療法後に皮膚症状が改善した 32 例に比 べて不変 14 例では, 好酸球数, 血清 $\operatorname{IgE}$ 及び血清 LDHが有意に高かった。皮膚症状の程度と血清 $\mathrm{LDH}$, 好酸球数及び血清 $\mathrm{IgE}$ は相関し, しかもその 相関の強さは血清 LDH, 好酸球数, 血清 $\operatorname{IgE}$ の順で あるとの向井らの報告と矛盾しない ${ }^{14)}$. 従って, これ ら 3 項目の検査值が高值ということは, より重症とい うことになり ${ }^{15)}$, 草津温泉療法はそれらのより重症例 には効果が少ないということにもなる。また，アトピ 
一性皮膚炎では種々の免疫学的異常が報告されてい る. 例元ば, PHA やCon A に対する反応性の低下 や CD8 陽性細胞の低下, CD4/CD8 陽性細胞比の増 加なども報告されているが4,16), 本研究ではそのよう な変化は, 温泉療法前後で認められなかった。

アトピー性皮膚炎の皮膚症状と黄色ぶどう球菌の関 連が指摘されている ${ }^{4,17)}$. 健常人の皮膚では, 普通, 黄色ぶどう球菌は検出されないが，アトピー性皮膚炎 患者の皮膚では皮膚症状の程度に応じて多数検出され $3^{10,17)}$. 掻痒部位を蛍爬するとそこで黄色ぶどう球菌 が繁殖し，その結果皮膚症状が悪化するという悪循環 が形成される. 黄色ぶどう球菌の関与はアトピー素因 などによる皮膚病変に対して二次的であると考えられ ているが, 黄色ぶどう球菌から産生される腸管毒, 中 毒性ショック症候群毒, 表皮剝離毒などが superantigens として作用している可能性も指摘されてい て興味深い ${ }^{17)}$.また, 黄色ぶどう球菌がアトピー性皮 膚炎患者の皮膚に繁殖しやすい機序として, corneocyte 膜上の fibronectin やlaminin が黄色ぶどう 球菌の受容体であることも明らかにされている17).

皮膚症状改善例では黄色ぶどう球菌が消失または減 少した成績から, 草津温泉療法がアトピー性皮膚炎に 効果的である理由として, pH 2.0 の酸性温泉水の殺 菌作用が第一に推定される.酸性水ならどれでも殺菌 作用があると思われるが，場合によってはかえって皮 膚症状を悪化させてしまう。草津温泉水には椂及な物 質が含まれていて，それらが皮膚を保護している可能 性も推定され, その検討は今後の課題である. また, 入浴する温泉水の温度を問題にする向きもあるが, 私

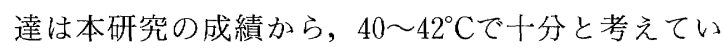
る. 草津温泉には約 130 年前の江戸期から,「時間湯」 と称される高温浴が伝えられてきた ${ }^{99} .47^{\circ} \mathrm{C}$ の温泉に 1 回 3 分, 1 日 3 4 回, 集団で入浴する方法である. 本来梅毒や䯪の治療に用いられてきたが, 現在でも, 好んで利用しているアトピー性皮膚炎患者も少なくな い.ただ，非常な高温浴で，火傷を負い当院に緊急入 院した症例が本研究の期間中に 2 例あったので,この ような高温浴には格段の注意が必要である.

次にもう一つの重要な症状である搔痒に対する効果 について考察する. 野口は高温浴 $\left(43 \sim 46^{\circ} \mathrm{C}\right)$ には搔 痒を鎮静する作用があると記載している ${ }^{18)}$.しかし， その効果は即効性ではあるものの一過性である ${ }^{18)}$. 私 達は既に草津温泉における「時間湯」入浴後に一過性
に血漿中の $\beta$-endorphin が上昇することを報告して いるが, 高温浴後の搔痒鎮静作用にはこの $\beta$-endorphin の関与の可能性も考えられる ${ }^{9}$. 実際，「時間湯」 の連浴によって搔痒が軽減し快感が得られたことか ら, $\beta$-endorphin 依存性と思われる症状を示したアト ピー性皮膚炎患者を私達は報告している ${ }^{199}$.

古くから温泉療法は皮膚疾患の治療に用いられてき た。最も効果がはっきりしている対象疾患は尋常性乾 癖である ${ }^{20,21)}$ ，アトピー性皮膚炎に対しては，野口は 秋田の玉川温泉 (酸性一アルミニウム一鉄-硫酸塩・塩 化物温泉）が効果があると報告し ${ }^{20)}$ ，中溝も大分の別 府温泉 (酸性-含硫黄-硫酸塩温泉) が有効と報告して いるが21), それらの研究が行われた時期は尋常性乾痽 に対する治療が主で，アトピー性皮膚炎についての詳 細は十分でない. 玉川温泉水の成分は草津温泉水のそ

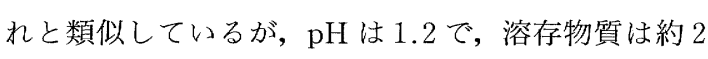
倍である.中でも塩素イオンの量は草津温泉水に比心 て約 8 倍である ${ }^{22)}$. 別府温泉水の成分も草津温泉水の

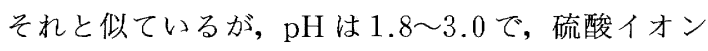
量を除いて溶存物質はやや少ない（大分県保健環境部 環境企画課の資料による)。なお，硫黄がアトピー性 皮膚炎に効果があるか否かについてはこれらの研究か らは明らかではない。また，フランスの Avene 鉱泉 （緩和性泉）では小児のアトピー性皮膚炎の治療に温 泉が用いられていると報告されている23).

以上，草津温泉療法のアトピー性皮膚炎に対する有 用性について報告したが, 草津温泉水は草津だけでし か利用できないので，多くのアトピー性皮膚炎の患者 には不便である。酸性なので, 一般の家庭には不向き である. 私達はこの研究をさらに発展させ, 草津温泉 水に含まれる有効成分を明らかにし，家庭でも利用で きる入浴法を確立し，本症に苦しむ患者に役立てたい と考えている.

[謝辞] 本研究に対し多大のご教示, ご助言をいただいた 群馬大学医学部皮膚科学 宮地良樹教授, 黒澤元博講師に 樑謝いたします。

\section{文献}

1) 西岡 清, 向井秀樹, 上村仁夫, 堀内保宏, 伊藤 篤, 野 口俊彦, 西山茂夫: 重症成人型アトピー性皮膚炎患者 の経過. 日皮会誌 $1988 ； 98: 873-877$

2）西岡 清: 成人型アトピー性皮虞炎. 医学の西的み $1994 ; 168: 745-748$

3）宮地良樹：アトピー性皮覤炎とは。思春期学 1992 ; 
10: $180-185$

4) Sampson HA: Atopic dermatitis. Ann Allergy $1992 ; 69: 469-479$

5）西岡 清: 成人型アトピー性皮膚炎.皮膚臨床 1991 ; 33: $413-418$

6）上原正巳：アトピー性皮膚炎の診断.アトピー性皮膚 炎のコンセンサスステートメント。医科学出版, 東京, $1994 ;$ pp 7-11

7）向山徳子：アレルギーマーチ.アトピー性皮膚炎と気 管支喘息の接点. ライフサイエンス・メディカ, 東京, 1994 ; pp 11-23

8）益子 安, 甘露寺泰雄：鉱泉分析法指針について.温泉 医学堤要. 日本温泉気候物理医学会, 東京, $1983 ; \mathrm{pp}$ 41-53

9) Kubota K, Kurabayashi H, Tamura K, Kawada E, Tamura J, Shirakura T: A transient rise in plasma $\beta$-endorphin after a traditional $47^{\circ} \mathrm{C}$ hot-spring bath in Kusatsu-spa, Japan. Life Sci 1992; 51: 18771880

10) Williams REA, Gibson AG, Aitchison TC, Lever R, Mackie RM: Assessment of a contact-plate sampling technique and subsequent quantitative bacterial studies in atopic dermatitis. Br J Dermatol $1990 ; 123$ : 493-501

11）菅井芳郎, 白倉卓夫, 布施正美: 草津温泉時間湯におけ る酸性泉浴湯皮膚炎患者の実態調査. 群馬医学 1983 ; 41:71-74

12）齋藤幾久次郎：湯中リ一内分泌 - 代謝に関する研究. 日温気誌 $1960 ； 24: 297-324$
13）宮地良樹：アトピー性皮膚炎の治療. 医薬の門 1992 ; $32: 248^{-251}$

14）向井秀樹, 野口俊彦, 上村仁夫, 西岡 清, 西山茂夫 : ア トピー性皮膚炎における血清 LDH（乳酸脱水素酵素） 活性值の変動. 日皮会誌 $1987 ; 97: 1623-1629$

15) Spitz E, Gelfard EW, Sheffer AL, Austen KF : Serum IgE in clinical immunology and allergy. J Allergy Clin Immunol $1972 ; 49$ : 337-347

16) Horan RF, Schneider LC, Sheffer AL: Allergic skin disorders and mastocytosis. JAMA 1992; 268: 2858-2868

17) Lacour $M$, Hauser $C$ : The role of microorganisms in atopic dermatitis. Clin Rev Allergy 1993; 11: 491-522

18）野口順一：皮膚疾患の水治療（特に浴法について）. 温 泉科学 $1990 ; 41: 75-76$

19) Kubota K, Tamura K, Take H, Kurabayashi H, Mori M, Shirakura T: Dependence on very hot hot-spring bathing in a refractory case of atopic dermatitis. J Med $1994 ; 25: 333-336$

20）野口順一：我国における皮膚病湯治の特異性. 日温気 物医誌 $1987 ; \mathbf{5 1}: 3-7$

21) 中溝慶生: 皮膚病の温泉理学療法. 日温気物医誌 $1992 ; \mathbf{5 6}: \mathbf{9 - 1 2}$

22）益子 安, 甘露寺泰雄: 鉱泉分析法指針について. 温泉 医学堤要 (日本温泉気候物理医学会 編). 日本温泉気 候物理医学会, 東京, $1993 ;$ pp 41-53

23）野口順一：フランシスの皮膚病湯治文献の紹介とその 読後感想 $(3)$. 日温気物医誌 $1986 ； 49: 187-190$ 